\title{
Correction to: Transformative experience and the shark problem
}

\author{
Tim Campbell ${ }^{1}$ (D) $\cdot$ Julia Mosquera $^{1}$
}

\section{Correction to: Philos Stud https://doi.org/10.1007/s11098-019-01382-1}

In the original publication of the article, the last paragraph on page 15 under Section 4 that reads "Finally, for reasons......outcomes to which it doesn't." was repeated. The correct paragraph is given below:

Finally, for reasons that we saw in Sect. 2, we do not think that appealing to vagueness will help with these problems. Suppose that some outcomes in S are borderline-it is neither determinately true that they are sharky nor determinately false that they are sharky - and that there is no higher-order vagueness. Should the agent follow the revelation approach when evaluating borderline outcomes, but not when evaluating sharky outcomes? If so, then in $\mathrm{S}$ there will be a sharp demarcation between outcomes to which the Revelation Approach applies and outcomes to which it doesn't.

Open Access This article is licensed under a Creative Commons Attribution 4.0 International License, which permits use, sharing, adaptation, distribution and reproduction in any medium or format, as long as you give appropriate credit to the original author(s) and the source, provide a link to the Creative Commons licence, and indicate if changes were made. The images or other third party material in this

The original article has been corrected.

The original article can be found online at https://doi.org/10.1007/s11098-019-01382-1.

The original version of this article was revised due to a retrospective Open Access order.

Julia Mosquera

julia.mosquera@iffs.se

Tim Campbell

timothy.campbell@iffs.se

1 Institute for Futures Studies, Holländargatan 13, Box 591, 10131 Stockholm, Sweden 
article are included in the article's Creative Commons licence, unless indicated otherwise in a credit line to the material. If material is not included in the article's Creative Commons licence and your intended use is not permitted by statutory regulation or exceeds the permitted use, you will need to obtain permission directly from the copyright holder. To view a copy of this licence, visit http:// creativecommons.org/licenses/by/4.0/. 